\title{
Temporal dynamics of soil nematode community structure under invasive Ambrosia trifida and native Chenopodium serotinum
}

\author{
W. J. LIANG ${ }^{1, *}$, F. P. LI $^{1,3}$, Q. LI ${ }^{1,3}$, W. D. ZHANG ${ }^{1,2}$ \\ ${ }^{1}$ Key Laboratory of Terrestrial Ecological Process, Institute of Applied Ecology, Chinese Academy of Sciences, \\ Shenyang 110016, China, E-mail: liangwj@iae.ac.cn; ${ }^{2}$ College of Life Sciences, Liaoning Normal University, \\ Dalian 116029, China; ${ }^{3}$ Graduate School of the Chinese Academy of Sciences, Beijing 100039, China
}

\begin{abstract}
Summary
Temporal dynamics of soil nematode community structure at the depth of $0-30 \mathrm{~cm}$ was compared under invasive Ambrosia trifida and native Chenopodium serotinum in an abandoned cropland in Northeast China. The results showed the difference of nematode taxa and dominant genera under $A$. trifida and $C$. serotinum during the study period. Acrobeloides and Paratylenchus were found to be dominant genera under both $A$. trifida and C. serotinum. Helicotylenchus prevailed in soil with $C$. serotinum, while $M a$ croposthonia was dominant in soil with $A$. trifida. Nematode taxa was higher under $A$. trifida than under $C$. serotinum from June to September. Except in the July, significantly higher numbers of plant-parasites were observed under $A$. trifida than under $C$. serotinum during the study period $(\mathrm{P}<0.05)$. Nematode taxa, Simpson index and structure index were found to be sensitive indicators that detected nematode community structural differences under A. trifida and C. serotinum during the study period.
\end{abstract}

Key words: soil nematode; community structure; temporal dynamics; invasive weed; Ambrosia trifida; abandoned cropland; Chenopodium serotinum

\section{Introduction}

Understanding the rapid proliferation of invasive species that are introduced into new regions of the world is one of the most important and difficult problems in ecology (Reinhart \& Callway, 2004). Invasive species are a major threat to biodiversity and ecosystem processes in native communities (Rejmanek \& Richardson, 1996; van der Putten et al., 2005) and it is widely assumed that invasive exotic plants cause a negative impact on native biota (Palmer et al., 2004).

Ambrosia trifida, an exotic invasive weed, is wide spread in Northeast China (Wang et al., 2005). It usually produces and releases volatile chemicals into the environment and may cause significant costs to agricultural production and public health (Sun et al., 2002). Previous studies have focused on the allelopathic potential of $A$. trifida (Wang et al., 2005), influence of $A$. trifida on total nematodes (Sun et al., 2002) and plant parasitic nematodes (Wang et al., 1998). However, little is known about the seasonal distribution of soil nematode community structure in an $A$. trifida habitat. The objectives of this study were to describe the temporal dynamics of soil nematode community structure under invasive $A$. trifida and native Chenopodium serotinum in an abandoned cropland in Northeast China.

\section{Material and Methods}

This study was conducted at the Shenyang Experimental Station of Ecology $\left(41^{\circ} 31^{\prime} \mathrm{N}, 123^{\circ} 22^{\prime} \mathrm{E}\right)$, Chinese Academy of Sciences, a Chinese Ecosystem Research Network (CERN) site in the lower reaches of the Liao River plain in Northeast China. The station is located in the continental temperate monsoon zone, with a dry-cold winter and a warm-wet summer. The annual mean temperature is $7.0-$ $8.0^{\circ} \mathrm{C}$, annual precipitation averages $650-700 \mathrm{~mm}$. The soil at the study site is an aquic brown soil (Liang et al., 2005c). Before the establishment of the station in 1989, all land was paddy fields with comparatively homogeneous and sufficient to maize production, and partly remained fallow (abandoned cropland) (Liang et al., 2005c). The abandoned cropland $(120 \mathrm{~m} \times 80 \mathrm{~m})$ was chosen for the study site, which was dominated by C. serotinum, Conyza canadensis, Humulus scandens, Metaplexis japonica. A. trifida was invaded in the abandoned cropland. In this study site we selected randomly three communities of $A$. trifida and C. serotinum, respectively. Soil samples were collected from the selected communities of $A$. trifida and $C$. serotinum at the depth of $0-30 \mathrm{~cm}$ from May to September, 2005. Each soil sample comprised 5 cores $(5 \mathrm{~cm}$ diameter); subsamples were taken from each such bulk sam-

\footnotetext{
* Corresponding author
} 
ple for estimation of nematode abundance. The rainfall and temperature at the study site recorded monthly during the study period (Fig. 1).

Nematodes were extracted from $100 \mathrm{~g}$ (fresh weight) of soil from each sample using sugar flotation and centrifuga- tion (Hua et al., 2006; Liu et al., 2006), the nematode abundance was expressed per $100 \mathrm{~g}$ dry weight soil (Liang et al., 2005a). All extracted nematodes in each sample were counted and identified to genus level using an inverted compound microscope. The classification of trophic groups

Table 1. The proportion (\%) of nematode genera and trophic groups under A. trifida and C. serotinum

\begin{tabular}{|c|c|c|c|c|c|c|c|c|c|c|}
\hline \multirow[t]{2}{*}{ Genus } & \multicolumn{5}{|c|}{ C. serotinum } & \multicolumn{5}{|c|}{ A. trifida } \\
\hline & May & Jun & Jul & Aug & Sep & May & Jun & Jul & Aug & Sep \\
\hline Bacterivores & 24.0 & 35.7 & 36.9 & 38.3 & 28.0 & 19.1 & 30.3 & 31.0 & $24.0 *$ & 20.5 \\
\hline Acrobeles & 1.0 & 2.5 & 3.3 & 2.0 & 1.9 & 0.9 & 5.5 & 1.6 & 1.7 & 3.5 \\
\hline Acrobeloides & 17.0 & 16.8 & 22.3 & 22.8 & 19.6 & 9.3 & $7.4^{*}$ & 20.8 & $9.4^{*}$ & 10.9 \\
\hline Alaimus & 0.0 & 0.1 & 0.0 & 0.0 & 0.0 & 0.0 & 0.9 & 0.2 & 0.3 & 0.0 \\
\hline Chiloplacus & 2.1 & 8.0 & 5.3 & 4.6 & 2.6 & 3.7 & 2.9 & 4.2 & 4.1 & 2.0 \\
\hline Eumonhystera & 0.0 & 0.0 & 0.0 & 0.0 & 0.0 & 0.0 & 0.0 & 0.0 & 0.2 & 0.0 \\
\hline Hetercephalobus & 0.4 & 0.2 & 0.2 & 1.0 & 2.1 & 0.0 & 0.1 & 0.8 & 0.5 & 1.4 \\
\hline Mesorhabditis & 0.0 & 1.0 & 0.4 & 3.2 & 0.2 & 0.0 & 2.8 & 1.7 & 1.8 & 1.1 \\
\hline Metateratocephalus & 0.0 & 0.0 & 0.0 & 0.0 & 0.0 & 0.0 & 0.1 & 0.0 & 0.0 & 0.0 \\
\hline Microlaimus & 0.0 & 0.2 & 0.0 & 0.0 & 0.0 & 0.0 & 0.0 & 0.0 & 0.0 & 0.0 \\
\hline Panagrolaimus & 0.0 & 0.0 & 0.0 & 0.1 & 0.0 & 0.0 & 0.0 & 0.2 & 0.3 & 0.1 \\
\hline Plectus & 0.0 & 0.0 & 0.2 & 0.2 & 0.0 & 0.2 & 0.3 & 0.0 & 0.1 & 0.0 \\
\hline Prismatolaimus & 2.4 & 0.0 & 0.7 & 0.8 & 0.6 & $0.0^{*}$ & $1.0^{*}$ & 0.0 & 0.4 & 0.4 \\
\hline Protorhabditis & 1.1 & 6.9 & 4.5 & 3.6 & 1.0 & 5.0 & 9.0 & 1.5 & 5.2 & 1.1 \\
\hline Rhabditophanes & 0.0 & 0.0 & 0.0 & 0.0 & 0.0 & 0.0 & 0.3 & 0.0 & 0.0 & 0.0 \\
\hline Fungivores & 3.3 & 4.1 & 2.9 & 2.3 & 2.1 & 2.9 & 4.4 & 2.7 & 2.6 & 4.7 \\
\hline Aphelenchoides & 0.0 & 0.0 & 0.0 & 0.4 & 0.4 & 0.5 & 0.2 & 0.5 & 0.3 & 0.2 \\
\hline Aphelenchus & 1.8 & 3.7 & 2.3 & 1.4 & 0.6 & 1.6 & 1.4 & 0.9 & 1.3 & 1.1 \\
\hline Diphtherophora & 0.0 & 0.0 & 0.0 & 0.0 & 0.0 & 0.0 & 0.0 & 0.0 & 0.0 & 0.7 \\
\hline Ditylenchus & 0.0 & 0.4 & 0.0 & 0.0 & 0.0 & 0.0 & 0.9 & 0.0 & 0.3 & 0.2 \\
\hline Tylencholaimus & 1.5 & 0.0 & 0.6 & 0.5 & 1.1 & 0.8 & $1.9^{*}$ & 1.3 & 0.7 & 2.5 \\
\hline Plant parasites & 69.2 & 55.9 & 59.6 & 58.4 & 68.8 & 74.8 & 62.1 & 64.6 & $72.1 *$ & 72.7 \\
\hline Boleodorus & 0.1 & 0.3 & 0.5 & 1.3 & 2.3 & 0.6 & 0.0 & 2.5 & 1.0 & 0.1 \\
\hline Coslenchus & 0.1 & 0.4 & 0.0 & 0.8 & 0.1 & 0.0 & 0.6 & 0.0 & 0.3 & 0.3 \\
\hline Filenchus & 1.7 & 3.2 & 3.2 & 1.4 & 6.1 & 2.5 & 4.5 & 1.2 & 2.1 & 2.6 \\
\hline Helicotylenchus & 33.3 & 7.4 & 1.1 & 15.5 & 32.2 & $4.5^{*}$ & 9.0 & 7.8 & 8.9 & $4.7^{*}$ \\
\hline Heterodera & 0.0 & 0.0 & 0.0 & 0.0 & 0.0 & 0.0 & 0.4 & 0.0 & 0.0 & 0.0 \\
\hline Macroposthonia & 1.4 & 9.4 & 9.5 & 6.4 & 4.6 & 3.3 & 5.9 & $26.0 *$ & $25.9^{*}$ & 7.3 \\
\hline Paratylenchus & 31.1 & 34.4 & 45.3 & 32.9 & 22.5 & $63.9 *$ & 41.3 & $26.6^{*}$ & 33.8 & $53.1 *$ \\
\hline Pratylenchus & 1.4 & 0.4 & 0.0 & 0.1 & 0.9 & 0.0 & 0.1 & 0.2 & 0.1 & 4.2 \\
\hline Psilenchus & 0.1 & 0.4 & 0.0 & 0.0 & 0.0 & 0.0 & 0.3 & 0.3 & 0.0 & 0.4 \\
\hline Rotylenchus & 0.0 & 0.0 & 0.0 & 0.0 & 0.1 & 0.0 & 0.0 & 0.0 & 0.0 & 0.0 \\
\hline Ominivores/predators & 3.5 & 4.3 & 0.6 & 1.0 & 1.1 & 3.2 & 3.2 & 1.7 & 1.3 & 2.1 \\
\hline Aporcelaimellus & 0.9 & 2.6 & 0.1 & 0.8 & 0.1 & 0.6 & 0.5 & 0.6 & 0.5 & 0.2 \\
\hline Dorylaimellus & 0.0 & 0.0 & 0.0 & 0.0 & 0.0 & 0.0 & 0.0 & 0.0 & 0.0 & 0.3 \\
\hline Dorylaimoides & 0.0 & 0.0 & 0.0 & 0.0 & 0.0 & 0.0 & 0.0 & 0.0 & 0.2 & 0.0 \\
\hline Epidorylaimus & 0.7 & 0.0 & 0.2 & 0.2 & 0.2 & 0.5 & 1.3 & 0.0 & 0.0 & 0.3 \\
\hline Eudorylaimus & 0.1 & 0.9 & 0.0 & 0.0 & 0.0 & 0.7 & $0.1^{*}$ & 0.0 & 0.2 & 0.0 \\
\hline Microdorylaimus & 1.6 & 0.4 & 0.3 & 0.0 & 0.4 & 0.6 & 0.8 & 0.6 & 0.1 & 0.2 \\
\hline Mononchus & 0.0 & 0.0 & 0.0 & 0.0 & 0.0 & 0.0 & 0.0 & 0.0 & 0.1 & 0.0 \\
\hline Nygolaimus & 0.0 & 0.0 & 0.0 & 0.0 & 0.0 & 0.3 & 0.0 & 0.2 & 0.0 & 0.1 \\
\hline Thonus & 0.1 & 0.4 & 0.0 & 0.0 & 0.4 & 0.5 & 0.5 & 0.3 & 0.2 & 0.9 \\
\hline Torumanawa & 0.1 & 0.0 & 0.0 & 0.0 & 0.0 & 0.0 & 0.0 & 0.0 & 0.0 & 0.0 \\
\hline
\end{tabular}

* denote differences in the proportions of nematode genera and trophic groups between $A$. trifida and C. serotinum at $\mathrm{P}<0.05$ level 
was assigned to: (1) bacterivores; (2) fungivores; (3) plantparasites; and (4) omnivores-predators, based on known feeding habitats or stoma and esophageal morphology (Yeates et al., 1993; Renčo, 2002; Liang et al., 2005a; Hua et al., 2006; Liu et al., 2006).

Nematode taxonomic and functional diversity was analysed by the following approaches: Simpson index was calculated to determine effects of plant species on nematode taxonomic diversity (De Deyn et al., 2004); Nematode taxa consisted of genera (De Deyn et al., 2004). The structure index (SI), enrichment index (EI) and channel index (CI) were indicators for soil food web structure and condition (indicating functional diversity) (Ferris et al., 2001; De Deyn et al., 2004; Liang et al., 2005b); they are calculated according to the method of Ferris et al. (2001), and the colonizer-persister (cp) values for taxa are adopted from Bongers (1990) and Bongers and Bongers (1998).

All the data were subjected to statistical analysis of variance (ANOVA) in the SPSS statistical package. Differences with $\mathrm{P}<0.05$ were considered significant.

\section{Results}

Altogether 39 genera of nematodes were identified in our investigation (Tab. 1). Acrobeloides and Paratylenchus were found to be dominant genera under $A$. trifida and $C$. serotinum. Helicotylenchus prevailed in soil with $C$. serotinum, while Macroposthonia was dominant in soil with $A$. trifida.

Plant parasitic nematodes were the most dominant trophic group under both $A$. trifida and $C$. serotinum, followed by bacterivores, fungivores and omnivores-predators were rare in our investigation. Significant plant species effects were found in the numbers of different trophic groups (Tab.
2). Except in the July, significantly higher numbers of plant-parasites were observed under $A$. trifida than under $C$. serotinum during the study period $(\mathrm{P}<0.05)$. Similar results were also found in the numbers of omnivore-predators in August and September, and the numbers of bacterivores in May, respectively $(\mathrm{P}<0.05)$.

In the present study, significant plant species and sampling month effects were found in the taxonomic diversity indices (Taxa and Simpson index) and the structural index (Tab. 3). The enrichment index was only sensitive to different sampling month $(\mathrm{P}<0.01)$. But only structural in-

Table 2. Abundance of nematode trophic groups under A. trifida and C. serotinum (numbers per $100 \mathrm{~g}$ dry soil)

\begin{tabular}{llcccc}
\hline & Sampling month & BF & FF & PP & OP \\
\hline May & A. trifida & $296 \mathrm{a}$ & $41 \mathrm{a}$ & $1193 \mathrm{a}$ & $44 \mathrm{a}$ \\
& C. serotinum & $226 \mathrm{a}$ & $28 \mathrm{a}$ & $758 \mathrm{~b}$ & $43 \mathrm{a}$ \\
Jun & A. trifida & $226 \mathrm{a}$ & $34 \mathrm{a}$ & $468 \mathrm{a}$ & $23 \mathrm{a}$ \\
& C. serotinum & $106 \mathrm{~b}$ & $13 \mathrm{a}$ & $181 \mathrm{~b}$ & $14 \mathrm{a}$ \\
\multirow{4}{*}{ Jul } & A. trifida & $196 \mathrm{a}$ & $16 \mathrm{a}$ & $397 \mathrm{a}$ & $6 \mathrm{a}$ \\
& C. serotinum & $172 \mathrm{a}$ & $12 \mathrm{a}$ & $304 \mathrm{a}$ & $4 \mathrm{a}$ \\
Aug & A. trifida & $274 \mathrm{a}$ & $37 \mathrm{a}$ & $1032 \mathrm{a}$ & $21 \mathrm{a}$ \\
& C. serotinum & $242 \mathrm{a}$ & $16 \mathrm{a}$ & $366 \mathrm{~b}$ & $5 \mathrm{~b}$ \\
Sep & A. trifida & $178 \mathrm{a}$ & $50 \mathrm{a}$ & $677 \mathrm{a}$ & $18 \mathrm{a}$ \\
& C. serotinum & $132 \mathrm{a}$ & $10 \mathrm{a}$ & $438 \mathrm{~b}$ & $5 \mathrm{~b}$ \\
Repeated measures & & & & \\
ANOVA & P-values & & & \\
Plant species & 0.03 & $<0.01$ & $<0.01$ & 0.01 \\
Month & 0.01 & $n s$ & $<0.01$ & $<0.01$ \\
Plant species $\times$ month & $n s$ & $n s$ & 0.01 & $n s$ \\
\hline
\end{tabular}

Explanations: $\mathrm{BF}$ - bacterivores; $\mathrm{FF}$ - fungivores; $\mathrm{PP}$ - plant parasites; $\mathrm{OP}$ - omnivores-predators; ns - no singnificant. Different letters denote divterences between $A$. trifida and $C$. serotinum at $\mathrm{P}<0.05$ level.

Tab. 3. Functional and taxonomic nematode diversity under A. trifida and C. serotinum

\begin{tabular}{|c|c|c|c|c|c|c|}
\hline \multirow{2}{*}{\multicolumn{2}{|c|}{$\begin{array}{l}\text { Sampling } \\
\text { month }\end{array}$}} & \multicolumn{2}{|c|}{ Taxonomic diversity } & \multicolumn{3}{|c|}{ Functional diversity } \\
\hline & & Taxa & Simpson & SI & EI & $\mathrm{CI}$ \\
\hline \multirow[t]{2}{*}{ May } & A. trifida & $9 a$ & $0.48 \mathrm{a}$ & $54 a$ & $44 a$ & $24 a$ \\
\hline & C. serotinum & $11 \mathrm{a}$ & $0.41 \mathrm{a}$ & $53 a$ & $20 \mathrm{a}$ & $60 \mathrm{a}$ \\
\hline \multirow[t]{2}{*}{ Jun } & A. trifida & $13 \mathrm{a}$ & $0.28 \mathrm{a}$ & $70 \mathrm{a}$ & $61 \mathrm{a}$ & $7 a$ \\
\hline & C. serotinum & $11 \mathrm{a}$ & $0.23 \mathrm{a}$ & $51 \mathrm{a}$ & $49 a$ & $24 \mathrm{a}$ \\
\hline \multirow[t]{2}{*}{ Jul } & A. trifida & $9 a$ & $0.27 \mathrm{a}$ & $33 a$ & $27 \mathrm{a}$ & $29 a$ \\
\hline & C. serotinum & $9 a$ & $0.32 \mathrm{a}$ & $38 \mathrm{a}$ & $42 \mathrm{a}$ & $28 \mathrm{a}$ \\
\hline \multirow[t]{2}{*}{ Aug } & A. trifida & $12 \mathrm{a}$ & $0.33 \mathrm{a}$ & $51 \mathrm{a}$ & $56 a$ & $13 a$ \\
\hline & C. serotinum & $10 \mathrm{a}$ & $0.30 \mathrm{a}$ & $29 b$ & $34 \mathrm{a}$ & $24 \mathrm{a}$ \\
\hline \multirow[t]{2}{*}{ Sep } & A. trifida & $11 \mathrm{a}$ & $0.40 \mathrm{a}$ & $51 \mathrm{a}$ & $27 \mathrm{a}$ & $21 \mathrm{a}$ \\
\hline & C. serotinum & $10 \mathrm{a}$ & $0.28 \mathrm{a}$ & $32 b$ & $16 a$ & $17 \mathrm{a}$ \\
\hline \multicolumn{2}{|c|}{ Repeated measures ANOVA } & P-values & & & & \\
\hline \multicolumn{2}{|c|}{ Plant species } & 0.03 & 0.04 & 0.02 & ns & ns \\
\hline \multicolumn{2}{|c|}{ Month } & 0.01 & $<0.01$ & $<0.01$ & $<0.01$ & ns \\
\hline \multicolumn{2}{|c|}{ Plant species $\times$ month } & ns & ns & ns & ns & ns \\
\hline
\end{tabular}

Explanations: SI - structure index; EI - enrichment index; CI - channel index; ns - no significant. Different letters denote differences between $A$. trifida and C. serotinum at $\mathrm{P}<0.05$ level 
dex showed differences in the August and September, with higher values found under the $A$. trifida $(\mathrm{P}<0.05)$.

The temporal fluctuations of temperature and rainfall in the study site were showed in fig.1. During the study period, the average temperature fluctuated slightly from $13.8^{\circ} \mathrm{C}$ in May to $19.3^{\circ} \mathrm{C}$ in July. The mean rainfall varied from 38.8 $\mathrm{mm}$ to $182.5 \mathrm{~mm}$, with the lowest in the September and the highest in the May. Significant correlation was only found between the numbers of fungivores and the rainfall $(r=$ $-0.936, \mathrm{P}<0.05)$.

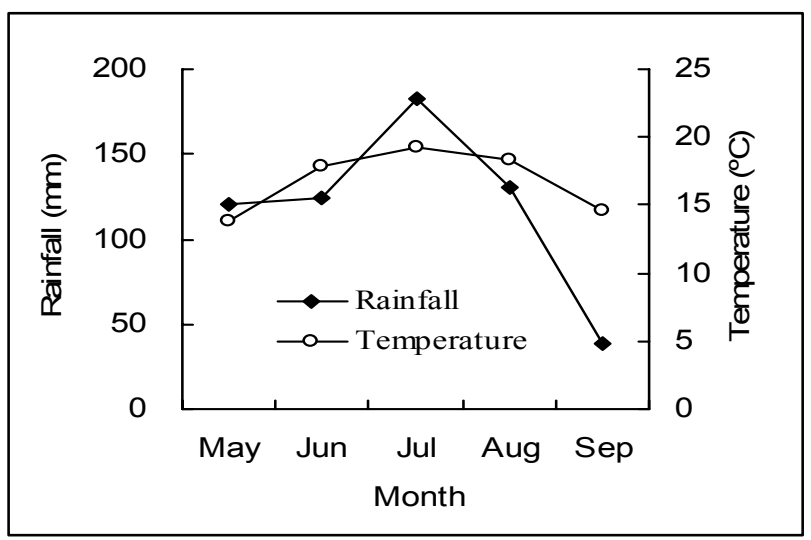

Fig. 1 Temporal fluctuations in rainfall and temperature at the study site during the study period

\section{Discussion}

The results showed the difference of nematode taxa and dominant genera under exotic $A$. trifida and native $C$. serotinum during the study period. Nematode taxa reflect biodiversity of soil habitat (Ou et al., 2005). In this study, the number of nematode genera was higher under $A$. trifida than under C. serotinum from June to September, 2005. This observation agrees with that of Yeates and Williams (2001) for a soil under the invasive weed Tradescantia fluminensis in New Zealand. Helicotylenchus prevailed in soil with $C$. serotinum, while Macroposthonia was dominant in soil with $A$. trifida. This is probably caused partially by differences in root exudates from $C$. serotinum and $A$. trifida (Wang et al., 1998).

There are some differences in soil nematode community structure under $C$. serotinum and $A$. trifida. Soil nematode communities under $A$. trifida were characterized by a high proportion of plant parasites $(69.3 \%)$, while those under C. serotinum dominated by plant parasites $(62.4 \%)$ and bacterivores $(32.6 \%)$. Our results were partially consistent with the findings of Van der Putten et al. (2005) that $A$. arenaria did not have more root-feeding nematode taxa in its natural range than in three out of four introduced regions. In our study, the relative higher abundance of bacterivores under $C$. serotinum might reveal that soil nematode community structure were changed due to the invasion of A. trifida, the abundance of plant-parasites showed more obvious response to the plant species than other trophic groups which partially consist with the results of De Deyn et al. (2004) that the abundances of the lower trophic consumers level were more affected than the higher trophic levels under different plant species. The different nematode communities under different plant species may have been due to low plant quality or plant defence compounds in the roots (Bardgett \& Wardle 2003; Van der Putten 2003), and the variation of nematode community composition might indirectly influence the soil processes.

Although plant species affected nematode abundance and community structure, we did not observe significant effects of plant species on the taxonomic diversity and indices of EI and CI in each sampling month. Only SI index showed differences in the August and September. The higher numbers of omnivore-predators could contribute to the higher values of SI which might indicate a complex community structure with many linkages in the food web under $A$. trifida.

Invasion of plants into new territories may greatly affect aboveground-belowground feedbacks, especially when the invading species has vastly different physiological traits from the native flora (Wardle et al., 2004). In the longer term these feedbacks can also involve the effect of the invader on the quantity and quality of resource inputs to soil and on decomposer organisms and the processes they drive (Ehrenfeld, 2003). Future studies may need to determine the effect of exotic $A$. trifida on nutrient cycling in abandoned cropland ecosystems.

\section{Acknowledgements}

This research was supported by the National Key Basic Research Support Foundation of China (No. 2005CB 121105) and the National Natural Science Foundation of China (No. 30570337). The authors thank Mr. J. Hua and staff of Shenyang Experimental Station of Ecology, Chinese Academy of Sciences for technical assistance.

\section{References}

BARdgetT, R. D., WARdLE, D.A. (2003): Herbivoremediated linkages between aboveground and belowground communities. Ecology, 84: 2258 - 2268

BONGERS, T. (1990): The maturity index: an ecological measure of environmental disturbance based on nematode species composition. Oecologia, 83: $14-19$

BONGERS, T., BONGERS, M. (1998): Functional diversity of nematodes. Appl. Soil Ecol., 10: 239 - 251

De Deyn, G. B., RaAijmakers, C. E., Van RuiJVen, J., Berendse, F., VAN DER PutTen, W. H. (2004): Plant species identity and diversity effects on different trophic levels of nematodes in the soil food web. Oikos, 106: $576-$ 586

EHRENFELD, J. E. (2003): Effects of exotic plant invasions on soil nutrient cycling processes. Ecosystems, 6: $503-$ 523

Ferris, H., Bongers, T., DE Goede, R, G. M. (2001): A framework for soil food web diagnostics: extension of the 
nematode faunal analysis concept. Appl. Soil Ecol., 18: 13 $-29$

HUA, J. F., JiAnG, Y., LiAng, W. J. (2006): Response of nematodes in a Hapli-Udic Argosol to urea amended with urease and nitrification inhibitors. Pedosphere, 16: $428-$ 434

Liang, W. J., Lavian, I., Pen-Mouratov, S., SteinberGER, Y. (2005a): Diversity and dynamics of soil free-living nematode populations in a Mediterranean agroecosystem. Pedosphere, 15: 204 - 215

LiAnG, W. J., Li, Q., JiAng, Y., NeHER, D. A. (2005b): Nematode faunal analysis in an aquic brown soil fertilized with slow-release urea, Northeast China. Appl. Soil Ecol., 29: $185-192$

LIANG, W. J., ZhaNG, X. K., LI, Q., JiANG, Y., OU, W., NEHER, D. A. (2005c): Vertical distribution of bacterivorous nematodes under different land uses. J. Nematol., 37: $254-258$

LiU, Y., Hua, J., Jiang, Y., LI, Q., Wen, D. (2006): Nematode communities in greenhouse soil of different ages from Shenyang suburb. Helminthologia, 43: 51-55

Ou, W., Liang, W. J., Jiang, Y., Li, Q., Wen, D. Z. (2005): Vertical distribution of soil nematodes under different land use types in an aquic brown soil. Pedobiologia, 49: $139-148$

PAlMER, M., Linde, M., Pons, G. X. (2004): Correlational patterns between invertebrate species composition and the presence of an invasive plant. Acta Oecologia, 26: $219-$ 226

Reinhart, K. O., Callaway, R. M. (2004): Soil biota facilitate exotic Acer invasions in Europe and north America. Ecol. Appl., 14: 1737 - 1745

REJMANEK, M., Richardson, D. M. (1996): What attributes make some plants more invasive? Ecology, 77: 1665
$-1661$

RENČO, M. (2002): Seasonal dynamics of plant parasitic and free living nematodes in sugar beet, cereals and lucerne fields in East Slovakia. Helminthologia, 39: 51 - 57

Sun, G., YIN, X. Q., ZU, Y. G. (2002): Preliminary studies on soil animals in a ragweed habitat. Acta Ecol. Sin. (in Chinese), 22: $608-611$

VAN DER PUTTEN, W. H. (2003): Plant defense belowground and spatiotemporal processes in natural vegetation. Ecology, 84: 2269 - 2280

van Der Putten, W. H., Yeates, G. W., Duyts, H., REIS, C.S., KARSSEN, G. (2005): Invasive plants and their escape from root herbivory: a worldwide comparison of the root-feeding nematode communities of the dune grass Ammophila arenaria in natural and introduced ranges. Biol. Invasi., 7: 733 - 746

Wang, P., Liang, W. J., Kong, C. H., JiAnG, Y. (2005): Allelopathic potential of volatile allelochemicals of Ambrosia trifida L. on other plants. Allelopathy J., 15: 131 $-136$

WANG, W., ZHU, X. R., LiU, W. Z. (1998): Influence of ragweed (Ambrosia trifida) on plant parasitic nematodes. $J$. Chem. Ecol., 24: 1707 - 1714

Wardle, D. A., Bardgett, R. D., Klironomos, J. N., Setälä, H., VAn der Putten, W. H., Wall, D. H. (2004): Ecological linkages between aboveground and belowground biota. Science, 304: 1629 - 1633

Yeates, G. W., Bongers, T., De Goede, R. G. M., Freckman, D. W., Georgieva, S. S. (1993): Feeding habits in soil nematode families and genera - an outline for soil ecologists. J. Nematol., 25: 315-331

Yeates, G. W., Williams, P. A. (2001): Influence of three invasive weeds and site factors on soil microfauna in New Zealand. Pedobiologia, 45: 367 - 383 